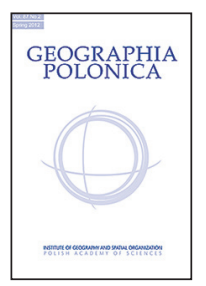 \\ INSTITUTE OF GEOGRAPHY AND SPATIAL ORGANIZATION \\ POLISH ACADEMY OF SCIENCES \\ www.igipz.pan.pl \\ www.geographiapolonica.pl
}

\title{
POLES IN THE INTERNATIONAL GEOGRAPHY OLYMPIAD (iGeo)
}

\author{
Marek Barwiński ${ }^{1}$ - Tomasz Sawicki ${ }^{2}$ - Joanna Uroda ${ }^{3}$ \\ Geography Olympiad Committee \\ ${ }^{1}$ University of Łódź \\ Faculty of Geographical Sciences \\ Kopcińskiego 31, 90-142 Łódź: Poland \\ e-mail: marbar@geo.uni.lodz.pl \\ ${ }^{2}$ c/o International Geographical Union Olympiad Task Force \\ Podbipięty 2, 02-732 Warsaw: Poland \\ e-mail: tomasz.j.sawicki@gmail.com \\ ${ }^{3}$ University of Warsaw \\ Faculty of Geology \\ Żwirki i Wigury 93, 02-089 Warsaw: Poland \\ e-mail: asia.uroda@gmail.com
}

\begin{abstract}
The article presents the nearly 20-year-long history of the International Geography Olympiad (iGeo) - from a modest start with 5 participating countries during the 1st Olympiad in The Hague, the Netherlands, to the 11th Olympiad that will be held this year in Krakow, Poland. The arrival of 37 teams from 5 continents has been confirmed. Poland has participated in all the iGeo's. Polish participants finished in the top places several times, both individually and as a team. These results showcase the high standards of the Polish students and their teachers as well as the effectiveness of the geography education provided in Poland.
\end{abstract}

\section{Key words}

geographical education • iGeo • International Geographical Union International Geography Olympiad 
Poland has the longest history of participation in the International Geography Olympiad, and prides itself on having an outstanding record of achievement in the competition. The Krakow Olympiad in 2014 marks the only time a country will have hosted the Olympiad twice.

The idea of organising an international geography competition for secondary school students dates back to the first half of the 1990s. The main goal was to promote geographical knowledge among young people through their natural will to compete and to build international links between people and places. Harnessing the potential of the increasingly popular - especially in Europe - national Geography Olympiads is also considered important.

Since 1974, a national Geography Olympiad has been held annually in Poland. From the outset, Poland was actively involved in developing the idea of organising an international competition. Poland, together with the Netherlands, were the originators of the International Geography Olympiad (iGeo). Poland, the Netherlands, and Slovenia have taken part in every event.

The first International Geography Olympiad for secondary school students (aged 16-19) was held in The Hague, the Netherlands, under the auspices of the International Geographical Union, in 1996. Only five countries (Belgium, Germany, the Netherlands, Poland, and Slovenia) took part. Since then, the number of countries participating has grown and the Olympic idea has considerably extended its geographical range (Tab. 1).

The International Olympiad was held biannually from 1996 to 2010, but a decision was taken to organise it every year starting from 2012. The Olympiads are generally scheduled just before Conferences or Congresses of the International Geographical Union. During the opening of a Conference (or a Congress) of the International Geographical Union, the closing ceremony of the Olympiad is held. At this time, the best students are awarded their gold medals. This naturally raises the prestige of the event. The 2004 and 2010 Olympiads were exceptions to this rule, being held elsewhere for organisational or safety reasons. Regional Olympiads were held between 2003 and 2011, when there was no global competition. Polish students were successful in the Central European Regional International Geography Olympiads. In 2009, the competition was held in Chorzów and Bielsko-Biała.

The most recent Olympiad, held in Kyoto, Japan, in 2013, was attended by 32 teams: Australia, Belgium, Belarus, Bulgaria, China, Croatia, the Czech Republic, Denmark, Estonia, Finland, Hong Kong, Hungary, Indonesia, Japan, Kazakhstan, Lithuania, Latvia, Macau, Mexico, Mongolia, the Netherlands, Nigeria, New Zealand, Poland, Russia, Romania, Singapore, Slovakia, Slovenia, Taiwan, the United Kingdom, and the USA. Forty-one

Table 1. International Geography Olympiad Events

\begin{tabular}{|c|l|l|c|}
\hline No. & Year & \multicolumn{1}{|c|}{ Location } & Number of participating countries \\
\hline I & 1996 & The Hague, the Netherlands & 5 \\
III & 1998 & Lisbon, Portugal & 5 \\
IV & 2000 & Seoul, South Korea & 13 \\
V & 2002 & Durban, South Africa & 12 \\
VI & 2004 & Gdynia, Poland & 16 \\
VII & 2006 & Brisbane, Australia & 23 \\
VIII & 2008 & Carthage, Tunisia & 24 \\
IX & 2012 & Taipei, Taiwan & 27 \\
X & 2013 & Cologne, Germany & 32 \\
\hline
\end{tabular}


teams from 39 countries (the People's Republic of China is represented by China, Macau and Hong Kong) have participated at least once.

The next Olympiad will be held in Krakow on 12-18 August 2014. This will make Poland the first country to have hosted the event twice. We expect 37 teams to participate. In addition to those already mentioned, e.g. Germany, Montenegro, Serbia, Tunisia, and Turkey have confirmed or are considering sending teams. The next two iGeos will be held in Moscow, Russia (2015), and Beijing, China (2016).

Each team is made up of four contestants aged 16-19, and two adult team leaders. One of the adult leaders is a member of the jury of the International Geography Olympiad. As all participants are selected in national geography contests, holding a national competition is a prerequisite for entering the International Geography Olympiad.

Since 2010, in accordance with the decision of the national Geography Olympiad Committee, Polish iGeo participants have been selected based on the Polish Geography
Olympiad finals and additional qualifying events. These qualifying events have taken the form of a camp to which the eight best contestants of the national Geography Olympiad are admitted. To qualify for the iGeo, the following factors are taken into consideration: national Olympiad finals result (weight: 60\%); fieldwork skills verified during the qualifying camp (20\%); and proficiency in English, which is the official language of the International Olympiad (20\%).

The International Geography Olympiad is composed of a written response test, fieldwork, and a multi-media test. There is no oral part.

Proposals for tasks can be submitted by any participating country. Subsequent development is then done by work groups appointed by the IGU Olympiad Task Force. Only the fieldwork part is prepared by the local organiser in consultation with the Task Force. Questions are generally related to global matters. The questions frequently check practical skills rather than factual knowledge. Details on how the iGeo tests are conducted and assessed, together with the

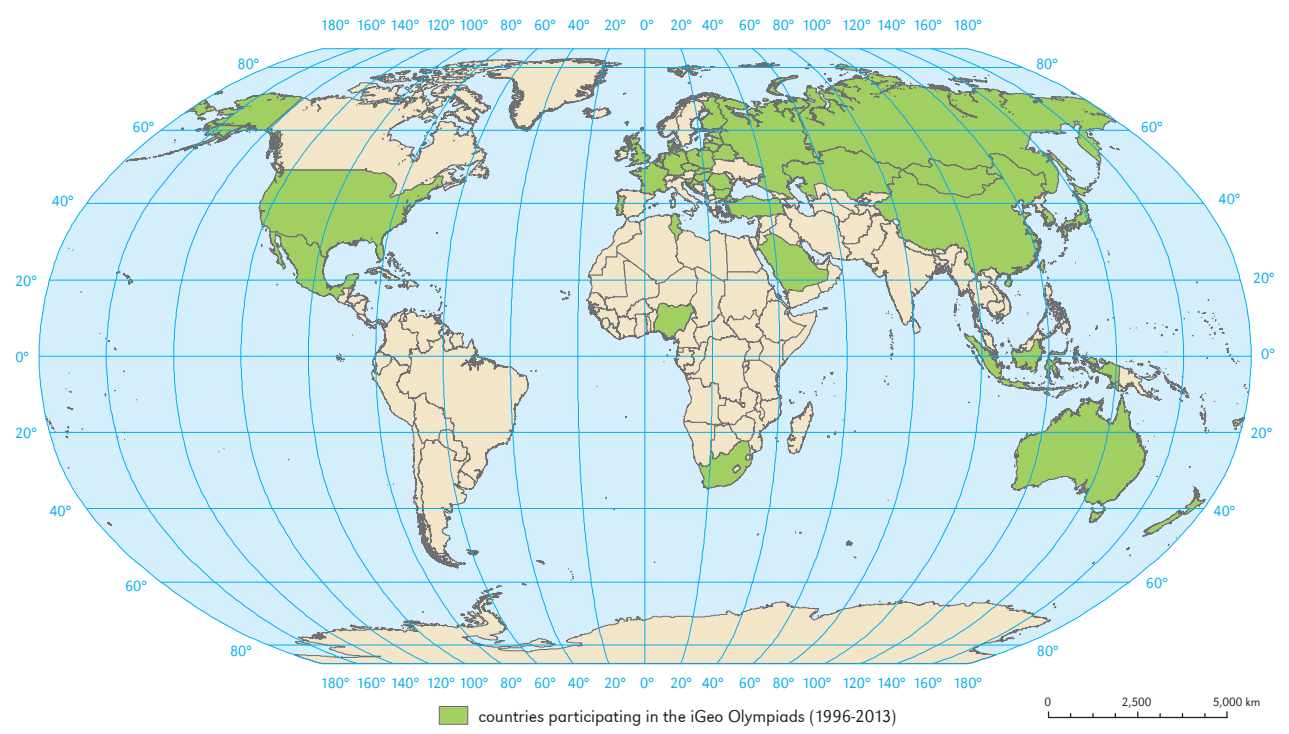

Figure 1. Countries participating in the International Geography Olympiad (1996-2013)

Source: Archive materials of the Geography Olympiad Committee. 
tasks from previous International Geography Olympiads, are available at the official website of the Olympiad - www.geoolympiad.org.

The fieldwork is definitely the most difficult part of the competition. It consists of an outdoor and an indoor stage. In the first, cartographic-stage, the students are required to prepare e.g. an inventory, a land use map or a land profile on the basis of their own field observations and supplied materials. The second stage, which involves using analytical and decision-making skills, includes such tasks as interpreting maps and aerial photographs, analysing the data collected during the field stage, or drawing up proposals to develop the area.

The Olympiad is not limited to the contest. All participants are required to prepare and deliver a 'cultural presentation' about their countries. This usually consists of singing, dancing or presenting folk costumes or items of broad cultural interest. The participants are additionally required to prepare a scientific poster before the competition. The poster has to address a topic selected by the Task Force, which will in turn be related to the theme of the next Conference or Congress of the International Geographical Union. The poster obviously has to be about the home country of the participants. It is presented to the public and assessed by the participants.

Granting awards to as many contestants as possible is one of the aims of the International Geography Olympiad. There are no prizes as such, but since the fifth iGeo in Gdynia, an impressive number of medals have been awarded. According to the rules, approx. $50 \%$ of participants go home with a medal. Given that over 30 countries, i.e. around $120-130$ students, take part, this means that approx. 10 gold, 20 silver, and 30 bronze medals are awarded. This is justified by both the marginal score differences between participants (often in the range of hundredths of a percent) and the fact that participants belong to a small group of the best young geographers in the world. The same practice is applied by international Olympiads in other subjects.
Poland has ranked among the leading countries in all ten previous Olympiads. Polish participants have won 21 medals, including 9 golds since 2004, when medals were first awarded. Poland has won five times as a team (including the first three Olympiads) and has four individual winners (1998, 2000, 2004, and 2006). Students from Poland were the most successful in the 2004 Olympiad held in Gdynia. They won 4 gold medals (and obviously won as a team). Two years later in Brisbane, Australia, 3 gold and 1 silver medal were won by Poles and once more they were the best team among 24 national teams. In 2012, they came in second individually and third as a team out of 32 countries in Cologne, Germany. Poland's record is summarised in Table 2.

There has been a large increase in the number of participants. Only five teams took part in the first iGeo, while the 10th event was attended by 32 teams. A growing number of participants is educated in English and regarded as native speakers and there have been constant changes in the curriculum and organisation of geography taught in Polish schools. Despite the above facts, students from Poland have been able to consistently maintain a very high position among the world's best, both individually and as a team', for 18 years.

Participating in the International Geography Olympiad gives secondary school students a chance to test their skills and knowledge, and to be compared with their peers from all over the world. Participating in the Olympiad is also a perfect opportunity to get to know some of the most exotic places on the planet where participants get to put their theoretical knowledge about geography into practice. These are all rewards for young people who have achieved extraordinary results

\footnotetext{
1 Students from Poland (up to 16 years old) have also been successful in international team competitions organised by the National Geographic Society (the National Geographic World Championship), while secondary school students took the top places in the Central European Regional International Geography Olympiad - CERIGEO - which was held from 2003 to 2011. More information is available on www.olimpiadageograficzna. edu.pl.
} 
Table 2. Poles in International Geography Olympiads from 1996 to 2013

\begin{tabular}{|c|c|c|c|c|c|}
\hline No. & City & Year & Participants & Medal $^{\star}$ - place individually & $\begin{array}{c}\text { Place } \\
\text { as a team }\end{array}$ \\
\hline I & The Hague & 1996 & $\begin{array}{c}\text { Krzysztof Rozenkiewicz } \\
\text { Łukasz Gagała } \\
\text { Wojciech Zalewski }\end{array}$ & $\begin{array}{c}3 \\
\text { distinction } \\
\text { distinction }\end{array}$ & 1 \\
\hline$\|$ & Lisbon & 1998 & $\begin{array}{c}\text { Katarzyna Kwiecińska } \\
\text { Jacek Zdrojewski } \\
\text { Szymon Fidziński } \\
\text { Krzysztof Dąbrowski }\end{array}$ & $\begin{array}{l}1 \\
2 \\
4 \\
6\end{array}$ & 1 \\
\hline III & Seoul & 2000 & $\begin{array}{c}\text { Adam Biliński } \\
\text { Magdalena Bieroza } \\
\text { Piotr Wilczyński }\end{array}$ & $\begin{array}{c}1 \\
3 \\
20\end{array}$ & 1 \\
\hline IV & Durban & 2002 & $\begin{array}{l}\text { Jakub Szmyd } \\
\text { Katarzyna Kot } \\
\text { Tomasz Sawicki } \\
\text { Iwona Oćwieja }\end{array}$ & $\begin{array}{l}4 \\
5 \\
5 \\
6\end{array}$ & 2 \\
\hline$\vee$ & Gdynia & 2004 & $\begin{array}{c}\text { Maciej Hermanowicz } \\
\text { Katarzyna Kazior } \\
\text { Jan Bolanowski } \\
\text { Piotr Tymoszuk }\end{array}$ & $\begin{array}{l}\text { gold }-1 \\
\text { gold }-2 \\
\text { gold }-3 \\
\text { gold }-5\end{array}$ & 1 \\
\hline $\mathrm{VI}$ & Brisbane & 2006 & $\begin{array}{c}\text { Jacek Próchniak } \\
\text { Jakub Redlicki } \\
\text { Artur Malantowicz } \\
\text { Tomasz Przeździecki }\end{array}$ & $\begin{array}{l}\text { gold }-1 \\
\text { gold }-2 \\
\text { gold }-8 \\
\text { silver - } 18\end{array}$ & 1 \\
\hline VII & Carthage & 2008 & $\begin{array}{c}\text { Piotr Żoch } \\
\text { Piotr Kosz } \\
\text { Michał Bil } \\
\text { Bartosz Gierlach }\end{array}$ & $\begin{array}{l}\text { silver - } 16 \\
\text { bronze } \\
- \\
-\end{array}$ & 9 \\
\hline VIII & Taipei & 2010 & $\begin{array}{c}\text { Bartosz Gierlach } \\
\text { Jan Kreft } \\
\text { Wojciech Kaczmarczyk } \\
\text { Wojciech Lechowski }\end{array}$ & $\begin{array}{c}\text { gold }-6 \\
\text { silver - } 18 \\
\text { bronze }-34 \\
\text { bronze }-36\end{array}$ & 3 \\
\hline IX & Cologne & 2012 & $\begin{array}{l}\text { Wojciech Kaczmarczyk } \\
\text { Wojciech Labuda } \\
\text { Jakub Mikrut } \\
\text { Kosma Nykiel }\end{array}$ & $\begin{array}{c}\text { gold }-2 \\
\text { silver - } 13 \\
\text { bronze }-38 \\
\text { bronze }-57\end{array}$ & 3 \\
\hline$x$ & Kyoto & 2013 & $\begin{array}{l}\text { Wojciech Labuda } \\
\text { Piotr Siwek } \\
\text { Jakub Wolak } \\
\text { Filip Matras }\end{array}$ & $\begin{array}{c}\text { silver - } 19 \\
\text { silver - } 25 \\
\text { bronze }-35 \\
-\end{array}$ & 5 \\
\hline
\end{tabular}

Source: www.olimpiadageograficzna.edu.pl/olimpiady-miedzynarodowe/igeo/.

* no medals were awarded prior to 2004 
in national competitions. It is a way of promoting the learning of geography and participating in national contests.

During the Olympiad the organisers are always keen to show participants the geographical, historical, and cultural attractions of the city and the region where the competition is being held. For the vast majority of students, this is their first visit to what is often a completely different geographical and cultural environment, which is frequently thousands of kilometres from home. In South Africa, students explored Durban, learnt the operating principles of NGOs involved in helping the poor, and visited parts of the KwaZulu-Natal region. In Australia, the participants took part in a walk through a rainforest, admired the Australian fauna, and watched an Australian football match. During the Olympiad in Tunisia, a 3-day field trip was organised. A tour of El Jem, a visit to the desert near Tozeur, and a trip to Chott el Djerid, a salt lake that dries up in the summer were all part of the agenda. In Taiwan, there was a visit to the earthquake museum in Wufeng, a taking in of the view of the capital from the 500-metre 'Taipei 101 ' tower, and a visit to the Yehliu Geopark, famous for its peculiar rock formations that overlook the Pacific. In Germany, participants visited gothic cathedrals, redeveloped mines and foundries in the Ruhr Area along with the idyllic agricultural areas of the Rhine Valley. In Japan, one of the world's oldest tectonic lakes (Lake Biwa) and 1000-year-old Buddhist temples 'hidden' in the mountains were visited.

After each iGeo, any team can participate - for an additional charge - in a field trip for a few days. This includes exploring the host country of the Olympiad. Special attention is given to strictly geographical elements, such as parts of the Australian interior, rock formations in the national parks of Taiwan, and the lava fields and caves at the foot of Mount Fuji in Japan. Visits to particular places are accompanied by a specialist in the field providing geographical commentary.

The International Geography Olympiad is also a way of comparing the results

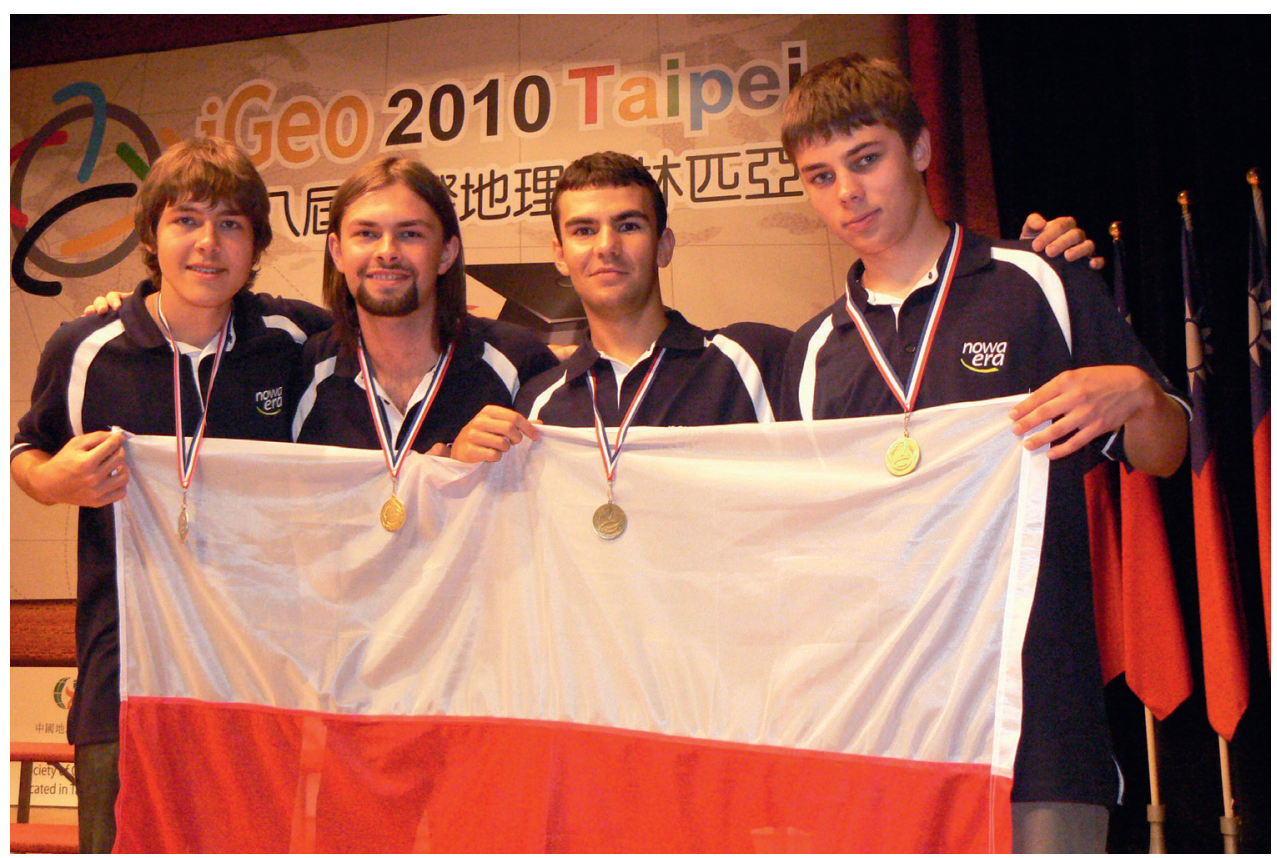

Figure 2. Polish medalist of the 8th iGeo in Taipei, Taiwan, from left: Jan Kreft (silver medal), Bartosz Gierlach (gold medal), Wojciech Lechowski (bronze medal), Wojciech Kaczmarczyk (bronze medal) 
of teaching geography in the Polish educational system with that of other countries. Given the results achieved by Polish students, this comparison is very positive and gives cause for optimism. Polish youth and the teaching of geography in Polish schools may be viewed more positively and optimistically as a result of the national and international Geography Olympiads.

\section{Editors' note:}

Unless otherwise stated, the sources of tables and figures are the author(s), on the basis of their own research.

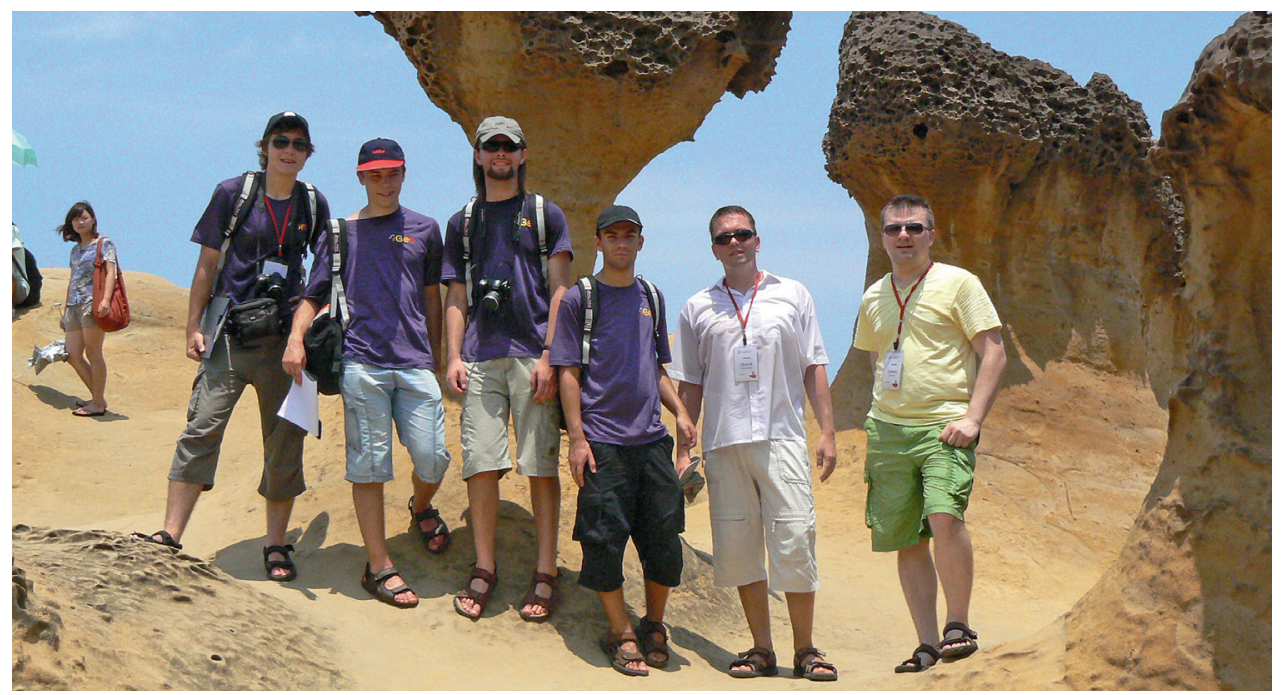

Figure 3. Polish team for the 8th iGeo in Yehliu Geopark, Taiwan, from left: Jan Kreft, Wojciech Kaczmarczyk, Bartosz Gierlach, Wojciech Lechowski, Marek Barwiński (Geography Olympiad Committee), Tomasz Sawicki (Geography Olympiad Committee)

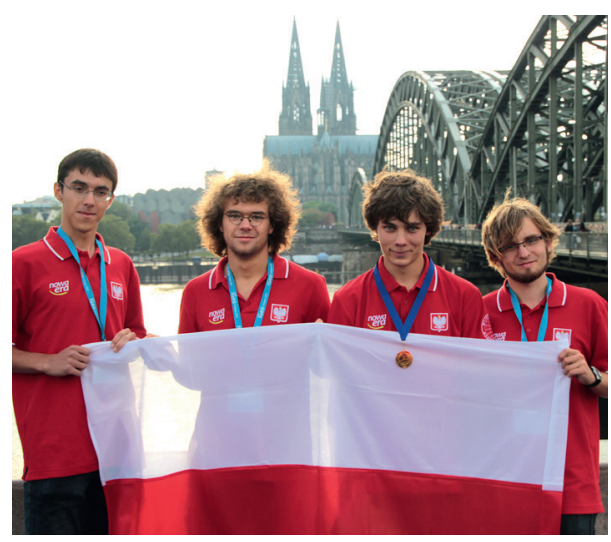

Figure 4. Polish team for the 9 th iGeo in front of the Cologne Cathedral, Cologne, Germany, from left: Wojciech Labuda (silver medal), Kosma Nykiel (bronze medal), Wojciech Kaczmarczyk (gold medal), Jakub Mikrut (bronze medal)

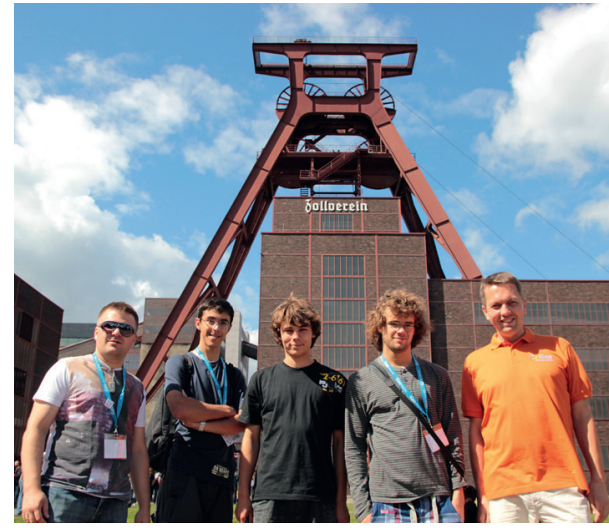

Figure 5. Polish team for the 9th iGeo, Essen, Ruhr Area, Germany, from left: Tomasz Sawicki (Geography Olympiad Committee), Wojciech Labuda, Wojciech Kaczmarczyk, Kosma Nykiel, Marek Barwiński (Geography Olympiad Committee) 


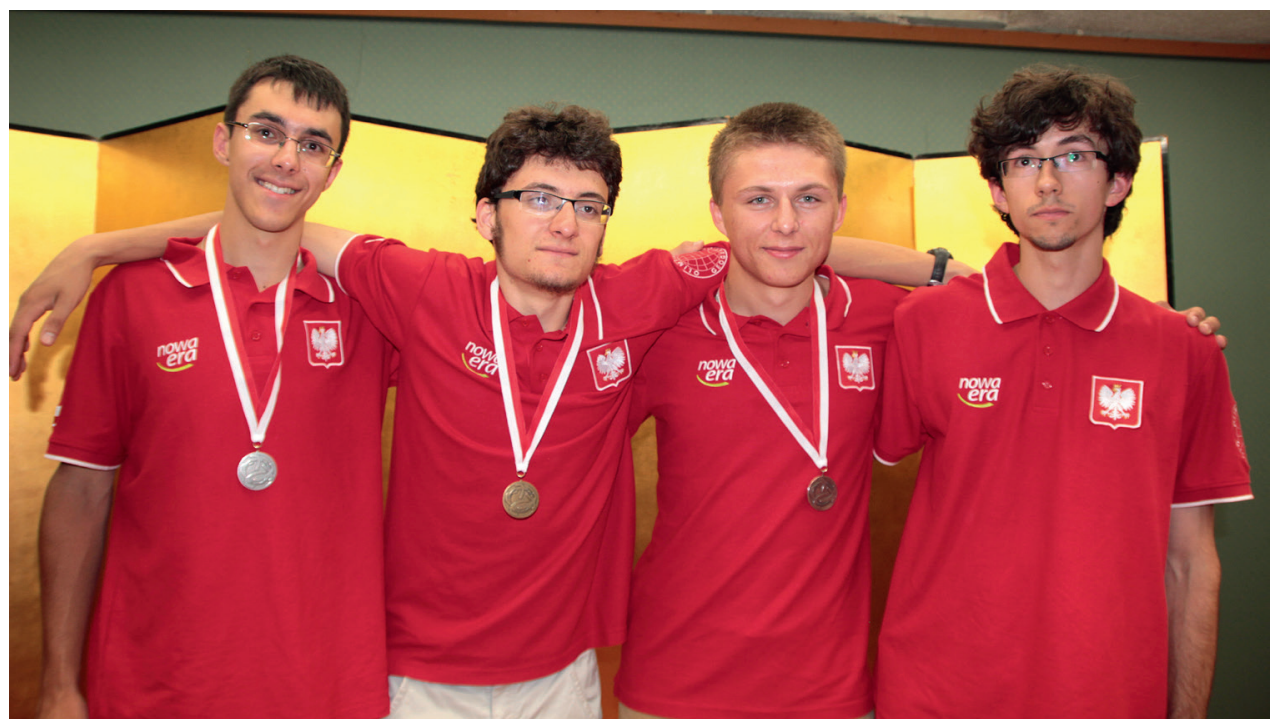

Figure 6. Polish team for the 10th iGeo in Kyoto, Japan. From left: Wojciech Labuda (silver medal), Jakub Wolak (bronze medal), Piotr Siwek (silver medal), Filip Matras

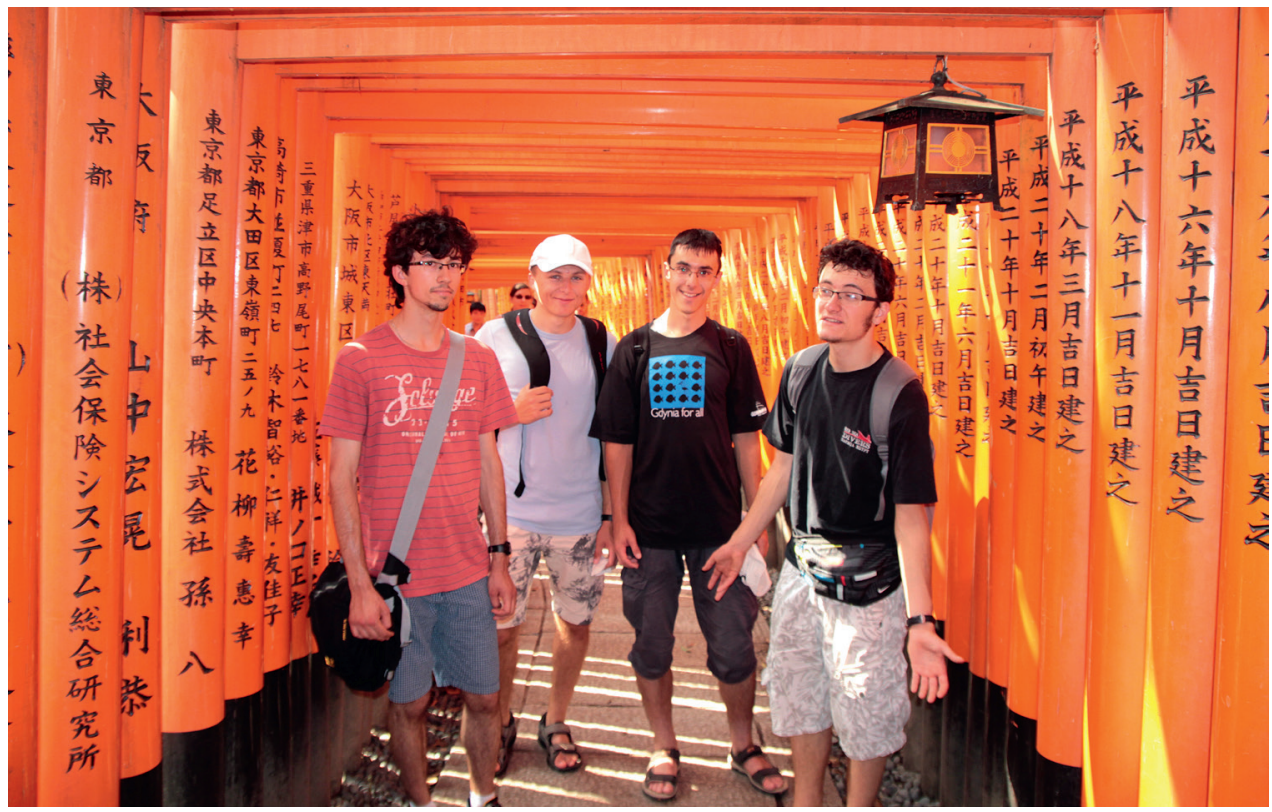

Figure 7. Polish team at the Fushimi Inari Shrine in Kyoto, Japan. From left: Filip Matras, Piotr Siwek, Wojciech Labuda, Jakub Wolak

(C) Marek Barwiński • Tomasz Sawicki • Joanna Uroda

(C) Geographia Polonica

(C) Institute of Geography and Spatial Organization

Polish Academy of Sciences - Warsaw • 2014
Article first received • November 2013 Article accepted • February 2014 